\title{
The Role of the Emotional Intelligence in Making Materials More Contextually Appropriate
}

\section{Роль емоційного інтелекту в актуалізації контекстуальності матеріалу, що вивчається}

\section{Eduard Ivashkevych}

Dr. in Psychology, Professor, Rivne State University of the Humanities, Rivne (Ukraine)

ORCID ID: https://orcid.org/0000-0003-0376-4615

Researcher ID: V-8872-2018

E-mail: ivashkevych.e@gmail.com

\section{Едуард Івашкевич}

Доктор психологічних наук, професор, Рівненський державний гуманітарний університет, м. Рівне (Україна)

\section{Ruslan Simko}

Ph.D. in Psychology, Senior Lecturer, Kamianets-Podilskyi National Ivan Ohiienko University, Kamianets-Podilskyi (Ukraine)

ORCID ID: https://orcid.org/0000-0002-9147-9541

Researcher ID: F-2765-201

E-mail: 7kort@ukr.net

\section{Руслан Сімко}

Кандидат психологічних наук, старший викладач, Кам'янець-Подільський національний університет імені Івана Огієнка, м. Кам'янець-Подільський (Україна)

The author's contribution: E. Ivashkevych-50\%, R. Simko-50\%.

Авторський внесок: Е. Івашкевич - 50\%, Р. Сімко- 50\%.

Address for correspondence, e-mail: kpnu_lab_ps@ukr.net Copyright: (C) Ivashkevych Eduard, Simko Ruslan

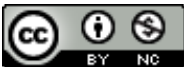
The article is licensed under CC BY-NC 4.0 International (https://creativecommons.org/licenses/by-nc/4.0/)

(C) Ivashkevych Eduard, Simko Ruslan

DOI (article): https://doi.org/10.32626/2227-6246.2020-48.112-132 


\section{ABSTRACT}

The purpose of the research is to provide theoretical justification and practical development of the perceptually-emotive component of communicative techniques as the ways of making materials more context appropriate. The last one in a great degree influences on the development of emotional intelligence of the person.

Methods of the research. The following theoretical methods of the research were used to solve the tasks formulated in the article: a categorical method, structural and functional methods, the methods of the analysis, systematization, modeling, generalization.

The results of the research. Emotions and perceptions in organizing a lesson of foreign languages were entrusted into many of the alternative and game techniques, pedestal and intensive ones. Heuristic learning is always open, which gives each teacher a space for creativity, develops and strengthens the pupils' perception of the educational material, the perception of school and a lesson as a whole. The educational material is considered and presented as a heuristic one. Only under this condition when the assimilation of the material takes place simultaneously at the level of data of two spheres - emotional and perceptual - we can tell about actualizing the emotional intelligence of the person. At the same time, the actual educational material is supplemented with positive background information in order to combine associative relationships with the positive emotions and emotional experiences, in particular among teenagers.

Emotional intelligence is the integrative concept and it includes a multitude of varied abilities, knowledge and skills, the importance and necessity of the development of which does not call into questions of psychologists and teachers. Researchers offer different variants of the structure of the emotional intelligence and conduct discussions about the components of this concept. Among the components of emotional intelligence, the authors singled out such abilities, as: 1) perception of emotions (identification of emotions by persons, in design, in music, in stories); 2) emotional assistance (transference of feelings, decision making on basis of emotions); 3) emotional understanding (definition of the subject of emotions, mixing the emotions, emotional transfer, emotional perspectives); 4) emotional control (managing one's own emotions, managing emotions of others).

Conclusions. In our research we proposed the following components of emotional intelligence: 1) self-consciousness (emotional self-consciusness,

(C) Ivashkevych Eduard, Simko Ruslan DOI (article): https://doi.org/10.32626/2227-6246.2020-48.111-132 
DOI: https://doi.org/10.32626/2227-6246.2020-48 2020. ВиПУСК 48

self-esteem, self-confidence); 2) social awareness (empathy, organizational awareness, self-orientation); 3) self-government (self-control, adaptability, initiative, orientation towards achievement); 4) social skills (leadership, influence, communication, actualization of personal changes, the behavior in conflict situations, the activity within micro-groups, link building).

It was shown that there were absolutely precise ways of determining different types of cognitive activity. Each person peculiarly combines different types of cognitive activity, each child has his / her own individual type of knowledge, which must correspond to their style of learning. Therefore, the main attention when working on the basis of the heuristic approach should be paid not to determine the type of cognitive activity of each pupil, but to use such a style of learning, in which pupils will be involved into various types of cognitive activity.

Before answering the teacher's questions, the pupil must extract the information required for the answer. It can be in the form of visual, auditory and kinesthetic (based on muscle senses) images. These processes occur at the level of consciousness. Then perceived information should also be presented visually, auditory and kinesthetically. This is a conscious action.

Key words: emotional intelligence, peculiarities of perception, perceptuallyemotive component of communicative techniques, self-consciousness, social awareness, self-government, social skills.

\section{Introduction}

The recent global geopolitical and economic changes put forward new training requirements. Thus, the growing need for specialists capable of freely communicating in foreign languages led to the orientation of teaching a foreign language to the development of a foreign language communicative competence. The process of formation of foreign-language communicative competence presupposes, the development of the communicative significance of simulated situations is the main task nowadays.

In the last decade a lot of interesting researches were done, the purpose of which was to improve the quality of teaching a foreign language at school. However, these researches were organized in practically the same direction, in the direction (c) Ivashkevych Eduard, Simko Ruslan

DOI (article): https://doi.org/10.32626/2227-6246.2020-48.112-132 
of streamlining and optimizing the methodology of teaching a foreign language at the expense of strengthening the person's activity on the development of pupils' memory, learning the lexical units necessary for the translation of texts.

Once again, to address the problem of teaching a foreign language, we were encouraged by the changes that took a great place at the present time at Ukrainian school. Today it is quite obvious that the purpose of teaching a foreign language in the junior classes involves developing the ability to read and to translate special literature. The development of intercultural communication, the expansion of international cooperation in various fields of the activity, set the task of having the means of intercultural communication of a specialist of any professional activity at the English lessons. Without having the opportunity to make adjustments to the terms of studying, for example, increasing the number of classrooms, individualized differentiated learning, internships for pupils being abroad, we have attempted to develop English learning tools based on the concept of perceptive-emotional component of communicative techniques as ways of making materials more context appropriate. We are talking about the emotions and perceptions of the main psychic phenomena that exercise have to influence necessarily on the nature of educational activities of people. In this case we mean the emotional intelligence of the person.

The relevance of our research is reasoned by the need to clarify and expand the notions of two important psychological phenomena - perception and emotion as means of teaching adolescents to speak a foreign language. Some psychologists (Honcharuk \& Onufriieva, 2018; Mykhalchuk, 2017) underline the dependence of the success of the study of non-native language according to the characteristics of the emotional and perceptual activity of pupils, and, in our opinion, a problem which needs further development and refinement remains.

The outlined problem is particularly relevant to the context of learning a foreign language by adolescents. The content

(C) Ivashkevych Eduard, Simko Ruslan DOI (article): https://doi.org/10.32626/2227-6246.2020-48.111-132 
DOI: https://doi.org/10.32626/2227-6246.2020-48 2020. випуск 48

of learning (assimilation of all types of speech activity, the formation of speech skills) involves the active use of emotional and perceptual processing of educational material. At the same time, for instructors of a middle level of teaching is a characteristic of the inadequacy of perception and assimilation of studied material, which is a consequence of pupil's nervous and mental exhaustion, which is associated with overload during the transition from the very beginning - from elementary school. On the other hand, adolescents do not have sufficiently complete and accurate representations about the potential possibilities of their own perceptual and emotional activity in the educational process. Speaking about the necessity of developing a set of abilities, qualities and characteristics, united by the concept of "emotional intelligence», it should be noted that the emotional skills and habits laid down in childhood, can become a determining factor for students for all subsequent life. Moreover, the ability to manage the emotional sphere more positively affects the mental and physical health of each child, while the lack of these abilities can lead to a fixed complex of qualities characterized by difficulties in understanding and identifying the person by his / her own emotions.

Emotions and perceptions in organizing a lesson of foreign languages were entrusted into many of the alternative and game techniques, pedestal and intensive ones. Heuristic learning is always open, which gives each teacher a space for creativity, develops and strengthens perception by pupils the educational material, the perception of school and a lesson as a whole. The educational material is considered and presented as a heuristic one. Only under this condition when the assimilation of the material takes place simultaneously at the level of data of two spheres - emotional and perceptual - we can tell about actualizing the emotional intelligence of the person. At the same time, the actual educational material is supplemented with positive background information in order to combine as(C) Ivashkevych Eduard, Simko Ruslan

DOI (article): https://doi.org/10.32626/2227-6246.2020-48.112-132 
sociative relationships with the emotional positive emotional experiences of adolescents.

The purpose of the research is to provide theoretical substantiation and practical development of the perceptually-emotive component of communicative techniques as the ways of making materials more contextually appropriate. The last one in a great degree influences on the development of emotional intelligence of the person.

\section{The tasks of the research}

1. To justify the meaning of the term «emotional intelligence» .

2. To propose the structure of «emotional intelligence» .

3. To describe the process of developing the emotional intelligence of teenagers permeates all levels of the teacher's activity.

4. To show eight ways of perceiving and understanding surrounding world.

5. According to these eight ways of perceiving and understanding surrounding world to propose exercises for teenagers, which, to our mind, in a great degree influence the development of pupils' emotional intelligence.

\section{Methods of the research}

The following theoretical methods of the research were used to solve the tasks formulated in the article: a categorical method, structural and functional methods, the methods of the analysis, systematization, modeling, generalization.

\section{Results and the discussion}

In recent years, the term «emotional intelligence» is used more and more frequently in Ukrainian and foreign methodological literature, which serves to represent the totality of abilities, knowledge and skills related to the regulation of the emotional sphere of the person and it is necessary for suc-

C Ivashkevych Eduard, Simko Ruslan DOI (article): https://doi.org/10.32626/2227-6246.2020-48.111-132 
cessful socialization and communication. Despite the fact that there is still no single position on the definition of emotional intelligence, scientists agree that this concept can combine the ability to distinguish and understand emotions, manage their own emotional states and emotions of partners of communication. At the same time, according to M. Smulson (Смульсон, 2000), the concept of «emotional intelligence» allowed researchers to look at the content of the emotional sphere in a new way and see that "people differ not only because of what they have emotional phenomena and how they proceed, but also after how they can deal with them».

Emotional intelligence is the integrative concept and it includes a multitude of varied abilities, knowledge and skills, the importance and necessity of the development of which does not call into questions of psychologists and teachers. Researchers offer different variants of the structure of the emotional intelligence and conduct discussions about the components of this concept. Among the components of emotional intelligence, the author M. Smulson (Смульсон, 2016) singled out such abilities, as: 1) perception of emotions (identification of emotions by persons, in design, in music, in stories); 2) emotional assistance (transference of feelings, decision making on basis of emotions); 3) emotional understanding (definition of the subject of emotions, mixing the emotions, emotional transfer, emotional perspectives); 4) emotional control (managing your own emotions, managing emotions of others).

So, we proposed the following components of emotional intelligence:

1) self-consciousness (emotional self-consciousness, selfesteem, self-confidence);

2) social awareness (empathy, organizational awareness, self-orientation);

3) self-government (self-control, adaptability, initiative, orientation towards achievement);

(C) Ivashkevych Eduard, Simko Ruslan

DOI (article): https://doi.org/10.32626/2227-6246.2020-48.112-132 
4) social skills (leadership, influence, communication, actualization of personal changes, the behavior in conflict situations, the activity within micro-groups, link building).

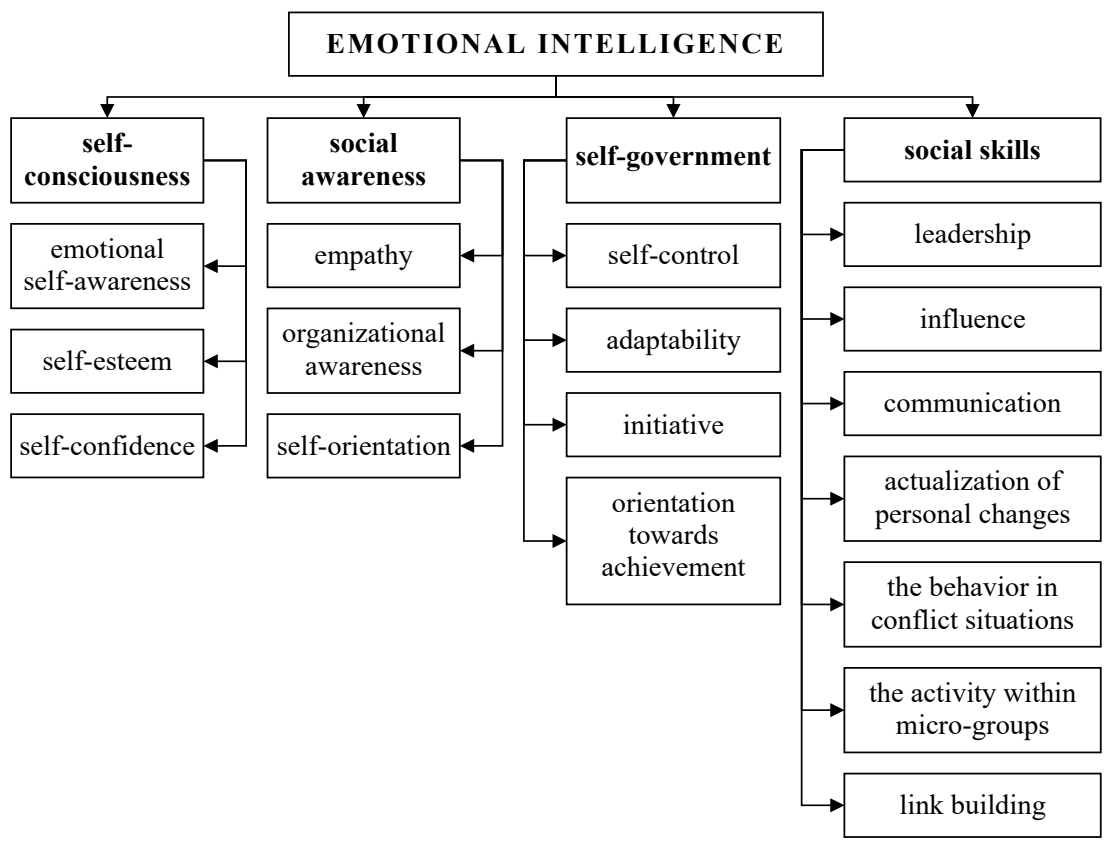

Fig. 1. Components of emotional intelligence of the person

Despite some differences in the approaches of identifying the components of emotional intelligence, most scholars agree that two main aspects need to be taken into account: the ability to manage his / her own emotions and create a supportive emotional atmosphere in relationships with other people. For school educators, the value of the emergence of this concept lies in the fact that it allows to implement an integrated approach to the development of critical emotional and social skills and abilities.

As for the process of teaching the foreign languages, the notion of "emotional intelligence» also has a certain interest,

C Ivashkevych Eduard, Simko Ruslan DOI (article): https://doi.org/10.32626/2227-6246.2020-48.111-132 
DOI: https://doi.org/10.32626/2227-6246.2020-48 2020. ВиПУСК 48

since its components (empathy, motivation for achievement, self-regulation, reflection, etc.) are necessary both for the full development of the emotional sphere of the child's person and for the successful beginning in the process of formation of a foreign language communicative competence of adolescents.

A lesson of a foreign language offers great opportunities for the development of perception and emotions of adolescents. In the context of a traditional school, a foreign language is one of a few subjects within which it is possible to simulate different communication situations that allow pupils to imagine themselves outside the school learning process and to work out certain behaviors in different communication situations. Perception and emotionality are important components of successful communication and can only be developed in the process of communication that is modeled at lessons of a foreign language. In addition, many specialists in the field of linguodidactics believe that learning a foreign language, especially by adolescence, greatly affects the formation of the person of a child and, in particular, his / her emotional sphere. In turn, the inclusion of the child's emotional-perceptual sphere in the process of studying a foreign language facilitates his / her successful assimilation. The emotional sphere, also with intellectual, plays the important role in the formation of language skills in native and foreign languages at school age.

There are a lot of approaches about the development of emotional intelligence of junior pupils, we can notice that the choice of approaches depends on what it is the primary for the teacher and the pupil: if the main goal is the formation and the development of the emotional intelligence of a child, then the development of emotional abilities, knowledge and skills are directly necessary. If the primary goal is different (in our case it is the formation and the development of a foreign language communicative competence), then the activity is done indirectly, that is, it combines language learning and the development of the emotional intelligence of children.

(C) Ivashkevych Eduard, Simko Ruslan

DOI (article): https://doi.org/10.32626/2227-6246.2020-48.112-132 
The process of developing the emotional intelligence of teenagers permeates all levels of the teacher's activity: planning of the lessons, the design of the classroom, the selection of educational material and exercises, the behavior of a teacher, the nature of the relationships in the classroom, both between the teacher and the pupils, and between the children themselves. However, one should pay attention to the fact that the use of such a fashionable concept of «emotional intelligence» now has not brought anything fundamentally new, revolutionary in the field of teaching children a foreign language. And this is not surprising, since many of those qualities and abilities that are considered as components of emotional intelligence have been the subject of studies of specialists in linguistics for a long time. There are some important factors in the developing of skills, of empathy, reflection, and motivation at foreign language lessons. At the same time, the combination of the most important abilities and skills associated with self-regulation and management of the emotional state in the process of communication, according to the concept of «emotional intelligence», allows us to imagine the problem of the development of the emotional sphere of a child in the complex, when all of the above capabilities are important both for the successful mastery of the foreign language and its further use, and for the full development of the emotional world of pupils.

Since the main goal of teaching foreign languages is the education of a person who is capable and willing to enter intercultural communication, it is desirable to create a model of such communication in the classroom. We have not forgotten that the teacher acted as a representative of another culture, his / her speech should be as close as it was possible to the natural, emotional speech in a foreign language, the speech had to be clearly individual. The conversation with the students should go "eyes to eyes», while the teacher must be on an equal footing with the students. When we tell about the age of teenagers, the teacher should lean towards the child, look into

(C) Ivashkevych Eduard, Simko Ruslan DOI (article): https://doi.org/10.32626/2227-6246.2020-48.111-132 
his / her eyes, so that he / she will feel the teacher's interest, which will give him / her confidence.

With regard to the design of the room for studying English, which is supposed to conduct training, it is recommended to create a cozy and comfortable room, avoiding bright colors, using decorative plants and flowers, and instead of Grammar tables and rules in the classroom there have to be quotes and pictures in English, which will help the child to adjust positively not only to a lesson of a foreign language, but also for the whole day.

Many teachers agree that during their studies children should not sit at the desks, and in the circle - on chairs or on a carpet. The form of the circle creates a sense of integrity, facilitates mutual understanding and interaction of children. At the lessons, it is desirable to use a large number of various and interesting toys, images of animals and fairy-tale characters.

In accordance with the principles of integral teaching of a foreign language, the selection of educational material should take place on the basis of the presence of positive background information in order to form associative relationships with the pupils' inner emotional experiences. A special role has to be given to music, which, to our mind, due to the ability of musical-acoustic stimuli to cause certain emotional states. Music is a kind of catalyst that accelerates the heuristic development of the child, his / her mental processes and personal qualities. In practice, the "emotional» effect of music is used to create motivation, eliminate emotional stress and stiffness, stimulate cognitive and associative processes, and ultimately the pupil's linguistic activity in the process of learning a foreign language.

In teacher's professional activity, everyone asks the question to himself / herself: "In order to remember a new word, a linguistic sample, a grammatical structure, etc., one pupil has only one period of time to hear, at that time how does the lack of series of lessons deal with their processing?»

(C) Ivashkevych Eduard, Simko Ruslan

DOI (article): https://doi.org/10.32626/2227-6246.2020-48.112-132 
Starting a search to answer to this question should be followed by watching the children at a break. In each classroom you can notice certain pupils with behavior that is characterized by their personal traits: one is always reading something, others draw on a board or anywhere, while others run in a classroom or in a hall, or, conversely, just sit in the classroom without paying attention to anyone, thinking about their own, etc.

All this is a presentation of psychological characteristics of these children, which each of them have had from their birth, the most expressed ones. In such a way children provide their abilities to perceive and understand the world around them.

According to H. Gardner, there are eight ways of perceiving and understanding surrounding world:

1. Linguistic perceiving and understanding - with the help of words, speech patterns, phrases.

2. Mathematical ones - using numbers, formulas, logics.

3. Spatial-visual perceiving and understanding - through vision and space.

4. Kinesthetic and tactile ones - through movements and actions.

5. Musical perceiving and understanding - through listening.

6. Extrovert ones - directed to others or through the surrounding world.

7. Introvert perceiving and understanding - directed through himself / herself.

8. Naturalistic one - through nature (Gardner, 1993).

Of course, these methods can not fail to be reflected in the practical work of a teacher who has to study his / her pupils well, their psychic peculiarities, because his / her task is to develop each person by the above-mentioned abilities as well as it is possible and thus contributes to the development of the personality of pupils.

(C) Ivashkevych Eduard, Simko Ruslan DOI (article): https://doi.org/10.32626/2227-6246.2020-48.111-132 
DOI: https://doi.org/10.32626/2227-6246.2020-48 2020. ВипУск 48

The teacher should therefore analyze himself / herself, because each of us has stronger or less pronounced one or another ability to perceive the world, and this, in turn, recognizes our methods and techniques of the activity. Teachers need to rely on a description that reveals the essence of each child, his / her preferences and needs, and also defines methods of the activity in the classroom in order to help the child to learn the teaching material more easily and to facilitate their process of studying English.

According to these eight ways of perceiving and understanding surrounding world we can propose exercises for teenagers, which, to our mind, in a great degree influence the development of pupils' emotional intelligence.

For example, there are exercises for "Linguistic perceiving and understanding - with the help of words, speech patterns, phrases".

Exercise 1. Read, listen and repeat the dialogue.

See: http://learnenglishteens.britishcouncil.org/skills/ listening-skills-practice/ introducing-friend.

- Hi, Pablo! How are you?

- Hi, Sumi ! I'm fine. Thanks.

- Pablo, this is Greta.

- Hi, Greta! I'm Pablo.

- Hi! How are you?

- I'm fine. Thanks. Where are you from, Greta?

- I'm from Germany. Where are you from?

- I'm from Argentina. Nice to meet you.

- Nice to meet you.

Exercise 2. Complete the sentences with the affirmative or negative forms of the verb "to be». Make them true for you.

1. $I$ 17 years old.

2. My sister / brother

3. My parents from Ukraine.

4. My friend and I students.

5. We in the classroom now.

C Ivashkevych Eduard, Simko Ruslan

DOI (article): https://doi.org/10.32626/2227-6246.2020-48.112-132 
DOI: https://doi.org/10.32626/2227-6246.2020-48

2020. випуск 48

6. My friends from London.

7. Our teacher Polish.

Exercise 3. Write questions. Use the interrogative of the verb "to be».

1. you / 17 years old?

2. you / from Ukraine?

3. your / favourite subject English?

4. your / friends at a lesson now?

5. you / happy?

6. your friends / students?

7. your parents / at home?

The example of «Extrovert exercises - directed to others or through the surrounding world" is:

Exercise 4. Work in pairs. Ask and answer the questions in exercise 3.

The next exercises are «Spatial-visual perceiving and understanding - through vision and space».

Exercise 5. Read about Diana's plans for summer, find the examples of "be going to" and complete the table.

\begin{tabular}{|c|c|}
\hline $\begin{array}{l}\mathrm{g} \\
\mathrm{s} \\
\mathrm{k} \\
\mathrm{e} \\
\mathrm{d} \\
\mathrm{d} \\
\mathrm{d} \\
\mathrm{y} \\
\mathrm{g} \\
\mathrm{l}\end{array}$ & 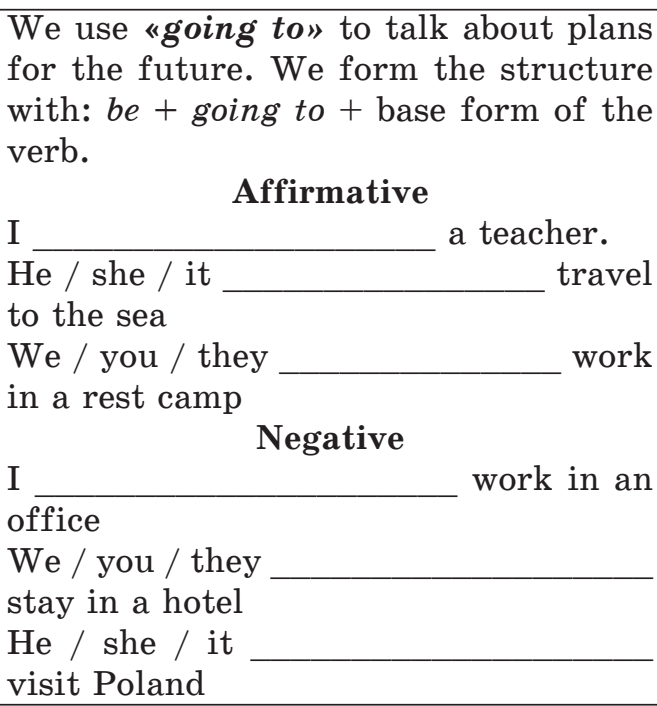 \\
\hline
\end{tabular}

(C) Ivashkevych Eduard, Simko Ruslan DOI (article): https://doi.org/10.32626/2227-6246.2020-48.111-132 


\begin{tabular}{|l|l|}
\hline \multicolumn{1}{|c|}{ Interrogative } \\
Are you / they / we going to work in a \\
shop? - Yes, I am. (No, I am not). Yes, \\
we / they are. (No, we / they are not) \\
What_do next? \\
\begin{tabular}{l} 
your friends? go out with \\
\hline
\end{tabular}
\end{tabular}

Exercise 6. What are your plans for this weekend? Find out your desk mate's plans for this weekend. Tick or cross the activities in the columns. Ask and answer about the activities. Work in pairs.

\begin{tabular}{|l|l|l|l|}
\hline \multicolumn{1}{|c|}{ activities } & you & your partner & your friend \\
\hline Watch TV & & & \\
\hline Surf the Internet & & & \\
\hline Go shopping & & & \\
\hline Go out with friends & & & \\
\hline Go to a disco club & & & \\
\hline Go to the cinema & & & \\
\hline Go jogging & & & \\
\hline Read a good book & & & \\
\hline Do homework & & & \\
\hline Work in the garden & & & \\
\hline Go to a library & & & \\
\hline
\end{tabular}

Model: Are you going to phone your friend? - Yes, I am / No, I am not.

Is your friend going to stay at home? - Yes, she / he is / No she / he is not.

When using the heuristic approach of teaching, it is important to combine, vary in the course of classes various activities focused on both types of cognition. Using different methods of diagnosis, you can make the idea of the dominant type of cognitive activity of the pupil and thereby expand (c) Ivashkevych Eduard, Simko Ruslan

DOI (article): https://doi.org/10.32626/2227-6246.2020-48.112-132 
the opportunities for more successful implementation of the heuristic approach.

\section{Conclusions}

In our research we proposed the following components of emotional intelligence: 1) self-consciousness (emotional self-awareness, self-esteem, self-confidence); 2) social awareness (empathy, organizational awareness, self-orientation); 3) self-government (self-control, adaptability, initiative, orientation towards achievement); 4) social skills (leadership, influence, communication, actualization of personal changes, the behavior in conflict situations, the activity within microgroups, link building).

It was shown that there are absolutely precise ways of determining different types of cognitive activity. Each person peculiarly combines different types of cognitive activity, each child has his / her own, individual type of knowledge, which must correspond to their style of learning. Therefore, the main attention when working on the basis of the heuristic approach should be paid not to determine the type of cognitive activity of each pupil, but to use such a style of learning, in which pupils will be involved into various types of cognitive activity.

Before answering the teacher's questions, the pupil must extract the information required for the answer. It can be in the form of visual, auditory and kinesthetic (based on muscle senses) images. These processes occur at the level of consciousness. Then perceived information should also be presented visually, auditory and kinesthetically. This is a conscious action.

The way of perception between a teacher and a pupil does not often coincide. For example, if a teacher prefers a form of a lecture, and a pupil has a poor auditory memory, the effectiveness of such activity will be small. If neither the teacher nor the pupil has sufficient flexibility to adapt to each other, this may ultimately have a serious impact on the effectiveness of learning, in the classroom environment. Thus, it is impor-

(C) Ivashkevych Eduard, Simko Ruslan DOI (article): https://doi.org/10.32626/2227-6246.2020-48.111-132 
DOI: https://doi.org/10.32626/2227-6246.2020-48

tant for the teacher to know the peculiarities of perception both their own and their pupils. Based on this knowledge, it is possible to help children to learn the teaching material, employing, as far as it is possible, all input channels.

\section{Literature}

Смульсон М. Л. Проектування дистанційних розвивальних середовищ. 2016. URL : psytir.org.ua/index.php/technology.../22/6.

Смульсон М. Л. Структура інтелекту: рефлексія та інтуїція. Психологія: Збірник наукових пращь НПУ іл. М. П. Драголанова. Київ, 2000. Вип. 11. С. 9-16.

Gardner, H. (1993). Multiple intelligences: the theory in practice. New York : Basic Books. 463 p.

Honcharuk, N., \& Onufriieva, L. (2018). Communicative needs in the structure of the intercourse process. Fundamental and Applied Researches in Practice of Leading Scientific Schools, 27 (3), 111-116. URL : https://farplss.org/index.php/journal/article/view/373.

Mykhalchuk, N. O. (2017). Psychological context of the idea of understanding. Психолінгвістика. Психолингвистика. Psycholinguistics. 2017. Вип. 22 (1). С. 163-175.

\section{References}

Smulson, M. L. (2016). Proektuvannia dystantsiinykh rozvyvalnykh seredovyshch [Designing remote developing environments]. Retrieved from psytir.org.ua/index.php/technology.../22/6 [in Ukrainian].

Smulson, M. L. (2000). Struktura intelektu: refleksiia ta intuitsiia [The structure of the intelligence: reflection and intuition]. Psykholohiia: Zbirnyk naukovykh prats NPU im. M. P. Drahomanova - Psychology: Collection of Scientific Articles of National Pedagogical University named after M. Drahomanov, 11, 9-16. Kyiv [in Ukrainian].

Gardner, H. (1993). Multiple intelligences: the theory in practice. New York : Basic Books.

Honcharuk, N., \& Onufriieva, L. (2018). Communicative needs in the structure of the intercourse process. Fundamental and Applied Researches in Practice of Leading Scientific Schools, 27 (3), 111-116. Retrieved from https://farplss.org/index.php/journal/article/ view/373.

Mykhalchuk, N. O. (2017). Psychological context of the idea of understanding. Psykholinhvistyka. Psikholingvistika. Psycholinguistics - Psycholinguistics. Psycholinguistics. Psycholinguistics, 22 (1), 163-175.

(C) Ivashkevych Eduard, Simko Ruslan

DOI (article): https://doi.org/10.32626/2227-6246.2020-48.112-132 http://journals.uran.ua/index.php/2227-6246 
Івашкевич Едуард, Сімко Руслан. Роль емочійного інтелекту в актуалізації контекстуальності матеріалу, що вивчається

\section{АНОТАЦІЯ}

Метою дослідження $\epsilon$ теоретичне обгрунтування та практичний розвиток перцептивно-емоційного компонента комунікативних прийомів як способів контекстуальної актуалізації навчального матеріалу. Останній значною мірою впливає на розвиток емоційного інтелекту людини.

Для розв'язання поставлених у роботі завдань використано такі теоретичні методи дослідження: категоріальний, структурно-функціональний, аналіз, систематизація, моделювання, узагальнення.

Результати дослідження. Емоції й емочійне сприйняття матеріалу відіграють суттєве значення в організації уроку іноземних мов. Перші становлять альтернативу багатьом навчальним та ігровим прийомам, а також можуть конкурувати з інтенсивним вивченням іноземних мов. Зазначено, що евристичне навчання завжди емочійне, відкрите, що дає кожному вчителеві неабиякий простір для творчості, розвиває й актуалізує не лише сприйняття учнями навчального матеріалу, а й сприйняття школи й уроку загалом. Наголошено, що навчальний матеріал має подаватися школярам в евристичний спосіб. Лише за цієї умови, коли опанування матеріалу відбувається одночасно на рівні двох сфер особистості - емоційної та перцептивної - ми можемо говорити щодо актуалізації емоційного інтелекту людини. Водночас, власне навчальний матеріал доповнюється позитивною довідковою інформацією з метою поєднання асоціативних зв'язків із позитивними емоціями й емочійними переживаннями, зокрема, в підлітковому віці.

Доведено, що емоційний інтелект є інтегративним утворенням, яке включає велику кількість різноманітних здібностей, знань і навичок, важливість і необхідність розвитку яких не викликає жодних сумнівів як у психологів, так і в учителів. Дослідники пропонують різні варіанти структури емочійного інтелекту та до сих пір ведуть дискусії щодо складових цього поняття. Серед компонентів емоційного інтелекту виокремлюють такі здібності, як: 1) сприйняття емоцій (ідентифрікація емочій з огляду на сприйняття іншої особи, оточуюче середовище, музику, розповідь тощо); 2) емочійна допомога іншій особі (передача почуттів, прийняття рішень на основі емоцій); 3) емочійне розуміння (визначення предмета емоцій, змішування емоцій, емочійне зараження, емоцій-

(C) Ivashkevych Eduard, Simko Ruslan DOI (article): https://doi.org/10.32626/2227-6246.2020-48.111-132 
на перспектива); 4) емоційний контроль (управління власними емоціями, управління емоціями інших).

Висновок. У своєму дослідженні нами було запропоновано такі компоненти емоційного інтелекту: 1) самосвідомість (емоційна самосвідомість, самооцінка, впевненість у собі); 2) соціальна обізнаність (емпатія, організаційна обізнаність, самоорієнтація); 3) самоврядування (самоконтроль, адаптованість, ініціативність, орієнтація на досягнення); 4) соціальні навички (лідерство, вплив, спілкування, актуалізація особистісних змін, поведінка в конфліктних ситуаціях, активність у межах мікрогруп, побудова зв'язків).

Було показано, що існують певні точні способи визначення різних видів пізнавальної діяльності. Кожна людина своєрідно поєднує різні види пізнавальної діяльності, у кожної дитини є свій, індивідуальний тип знань, який повинен відповідати ії стилю навчання. Тому головну увагу в шкільному навчанні слід приділяти не визначенню типу пізнавальної діяльності, який підходить для кожного окремого учня, а використанню такого стилю навчання, за умов дотримання якого учні залучатимуться до різних видів пізнавальної діяльності.

Перш ніж відповісти на запитання вчителя, учень має актуалізувати інформацію, необхідну для відповіді. Ця інформація постає у вигляді зорових, слухових і кінестетичних (на основі м'язових відчутmів) зображень. Мисленнєві процеси, не зважаючи на те, що вони супроводжуються емоційним реагуванням, відбуваються на рівні свідомості. Отже, емоційний інтелект есплікується у цілковито свідомих патернах.

Ключові слова: емоційний інтелект, особливості сприйняття, перцептивно-емоційний компонент комунікативних прийомів, самосвідомість, соціальна обізнаність, самоврядування, соціальні навички.

\section{Ивашкевич Эдуард, Симко Руслан. Роль эмоционального интеллекта в актуализации контекстуальности материала, который изучается}

\section{АННОТАЦИЯ}

Целью исследования является теоретическое обоснование и практическое развитие перцептивно-эмоционального компонента коммуникативных приемов как способов контекстуальной актуализации учебного материала. Последний в значительной степени влияет на развитие эмоционального интеллекта человека.

(C) Ivashkevych Eduard, Simko Ruslan

DOI (article): https://doi.org/10.32626/2227-6246.2020-48.112-132 
DOI: https://doi.org/10.32626/2227-6246.2020-48 2020. випуск 48

Для решения поставленных в работе задач использованы следующие теоретические методы исследования: категориальный, структурно-функциональный анализ, систематизация, моделирование, обобщение.

Результаты исследования. Эмоции и эмоциональное восприятие материала играют существенное значение в организации урока иностранного языка. Первые составляют альтернативу многим учебным и игровым приемам, а также могут конкурировать с интенсивным изучением иностранных языков. Отмечено, что эвристическое обучение всегда эмоциональное, открытое, что предоставляет каждому учителю большой простор для творчества, развивает и актуализирует не только восприятие учащимися учебного материала, но и восприятие школы и урока в целом. Отмечено, что учебный материал должен подаваться школьникам в эвристической форме. Только при соблюдении условия, что овладение материалом происходит одновременно на уровне двух сфер личности - эмоциональной и перцептивной - мы можем говорить об актуализации эмоционального интеллекта человека. В то же время, собственно учебный материал дополняется определенной информацией с целью объединения ассоциативных связей с положительными эмоциями и эмоциональными переживаниями, в частности, в подростковом возрасте.

Доказано, что эмоциональный интеллект является интегративным образованием, которое включает большое количество разнообразных способностей, знаний и навыков, важность и необходимость развития которых не вызывает никаких сомнений как у психологов, так и у учителей. Исследователи предлагают различные варианты структуры эмоционального интеллекта и до сих пор ведут дискуссии о составляющих этого понятия. Среди компонентов эмоционального интеллекта выделяются такие способности, как: 1) восприятие эмоций (идентификация эмоций, учитывая восприятие другого человека, окружающую среду, музыку, рассказы и др.); 2) эмоциональная помощь другому человеку (передача чувств, принятие решений на основе эмочий); 3) эмочиональное понимание (определение предмета эмоций, смешивание эмоций, эмоциональное заражение, эмоциональная перспектива); 4) эмоциональный контроль (управление собственными эмоциями, управление эмоциями других).

Вывод. В своем исследовании нами были предложены следующие компоненты эмоционального интеллекта: 1) самосознание (эмоцио-

(C) Ivashkevych Eduard, Simko Ruslan DOI (article): https://doi.org/10.32626/2227-6246.2020-48.111-132 
DOI: https://doi.org/10.32626/2227-6246.2020-48 2020. ВИПУСК 48 нальное самосознание, самооценка, уверенность в себе); 2) социальная осведомленность (эмпатия, организационная осведомленность, самоориентация); 3) самоуправление (самоконтроль, адаптация, инициативность, ориентация на достижения); 4) социальные навыки (лидерство, влияние, общение, актуализация личностных изменений, поведение в конфликтных ситуациях, активность в пределах микрогрупп, построение связей).

Было показано, что существуют точные способы определения различных видов познавательной деятельности. Каждый человек своеобразно объединяет различные виды познавательной деятельности, у каждого ребенка есть свой, индивидуальный тип знаний, который должен соответствовать его стилю обучения. Поэтому основное внимание в школьном обучении следует уделять не определению типа познавательной деятельности, который подходит для каждого отдельного ученика, а использованию такого стиля обучения, при условии соблюдения которого ученики будут привлекаться к различным видам познавательной деятельности.

Прежде чем ответить на вопрос учителя, ученик должен актуализировать информацию, необходимую для ответа. Эта информация появляется в виде зрительных, слуховых и кинестетических (на основе мышечных ошущений) изображений. Мыслительные процессы, несмотря на то, что они сопровождаются эмоциональным реагированием, происходят на уровне сознания. Итак, эмоциональный интеллект эксплицируется в полностью сознательных паттернах.

Ключевые слова: эмоциональный интеллект, особенности восприятия, перцептивно-эмоциональный компонент коммуникативных приемов, самосознание, социальная осведомленность, самоуправление, социальные навыки.

Original manuscript received February 04, 2020

Revised manuscript accepted March 02, 2020

(C) Ivashkevych Eduard, Simko Ruslan

DOI (article): https://doi.org/10.32626/2227-6246.2020-48.112-132 